\title{
ATT GESTALTA CHTHULUCENEN
}

Om hur kvinnor stärker släktbanden med havssköldpaddor i Nicaragua

JUAN VELÁSQUEZ ATEHORTÚA

I naturreservatet El Estero, i Nicaraguanska fiskebyn Padre Ramos, finns de största mangroveskogarna i Centralamerika. Skogarna besöks årligen av karettsköldpaddor (Eretmochelys imbricata) som kommer dit för att lägga sina ägg. Eftersom arten är utrotningshotad startade en transnationell forskargrupp ett samarbete med de lokala invånarna för att utse sköldpaddorna till sin så kallad flagskeppsart. I arbetet för att rädda arten fick männen i byn, som familjeförsörjande fiskare, ekonomisk ersättning för att hantera sköldpaddorna (Liles m.fl. 2016; 2019). Kvinnorna fortsatte ta hand om såväl bebyggelsens framväxt som familjerna.

Den här artikeln har fokus på hur kvinnorna tillkämpar sig en vårdande roll och gestaltar Chthulucenen (Haraway 2015, 2016) i fältet mellan karettskölpaddorna, den transnationella forskargruppen, männen i byn, NGO:er och kommunen. Chthulucenen är, enlig Haraway, tiden när människor stärker sina släktband med alla andra arter för att tillsammans bättre kunna leva och dö på jorden (Haraway 2016:105). Kvinnorna och byborna gestaltar Chthulucenen i Padre Ramos genom att använda teknologier för att säkra sköldpaddornas reproduktion och genom en olydnadsaktion, dvs. i form av en markockupation som är ämnat för att bygga en lekpark med karettsköldpaddor som tema. Med olydnadsanktioner fungerar kvinnorna som allierade släktingar till sköldpaddorna - som metaforiska „småkryp“ $i$ en komposthög transformerar de ruttet myndighetsmaterial till fruktbar samhällsutveckling. Som det framgår i artikeln har dessa olydnadsaktioner en helande funktion och bör därför betraktas som ett grundläggande inslag i Chthulucenen. Lekparken som skulle byggas var vid tidpunkten den enda säkra välfärdsinsatsen som kommit byn till gagn genom europeiska NGO-pengar. Lekparken kom på så sätt att bli ett monument över flagskeppsartens arbete som helande kraft i naturreservatet, men vars byggande illustrerar att läkningen av relationer inte är konfliktfri. 
Padre Ramos ligger ungefär 100 kilometer söder om Fonsecabukten på nordvästra hörnet av Nicaraguas gräns mot Honduras och El Salvador. Fattigdom har gjort att de årliga ankomsterna av karettsköldpaddor har använts av byborna både som föda och som inkomstkälla (Fauna y Flora internacional 2011; Lies m.fl. 2015a, 2015b, 2016, 2019). Människors lokala utnyttjande av arten, tillsammans med temperaturhöjningar orsakade av den globala klimatkrisen, har gjort att sköldpaddorna är på gränsen till utrotning. Forskarna kom fram till att antalet levande sköldpaddor år 2015 var under 500 stycken. Sköldpaddorna lägger sina ägg till en viss utsträckning längst Stilla havets långa kuststräckan mellan Mexico och Peru, men de huvudsakliga platserna är Fonseca Bukten (75 procent), naturreservatet Jiquilisco-viken i El Salvador (35 procent) och El Estero de Padre Ramos i Nicaragua (40 procent) (Liles m.fl. 2016:207). Forskargruppen bakom denna kartläggning arbetade under Östra Stillahavets Karett-initiativet (The Eastern Pacific Hawksbill Initiative). För att rädda arten ville forskarna knyta ihop naturreservaten längst Stilla havets kust med varandra. Detta för att hitta bra platser för sköldpaddorna att lägga äggen samtidigt som man skulle söka att få byborna att ställa om från jägare till vårdare av sköldpaddorna. I Padre Ramos ville forskarna köpa äggen från äggsamlare (tortugueros) för att bryta den traditionella försäljningen av äggen på marknader och istället få dessa till att delta $\mathrm{i}$ ett konserveringsprojekt som kläcker äggen för att sen släppa ungarna fria i havet (Lies m.fl. 2019:1608; Lies m.fl. 2016:207).

Då Padre Ramos utgör en unik häckningsplats föreslog forskarna att byn kunde utse karettsköldpaddan till sin flaggskeppsart. De utgick från en vision att de lokala samhällena skulle adoptera en utrotningshotad art för att marknadsföra byn, där den vistas i och vårdas för sin fortlevnad (Veríssimo o.a. 2011; citerad i Liles m.fl. 2016:208). Mellan 2012 och 2014 arrangerade forskargruppen en tävling där Jiquilisco och Padre Ramos förenades över nationsgränserna - i känslan att tillsammans rädda arten (Liles m.fl. 2016:214). Utan dessa samarbeten mellan forskare och byborna skulle de höjda havstemperaturnivåerna slå ut arten inom ramen för hundra år (Liles m.fl. 2019:1605).

Jag kom $i$ kontakt med denna historia genom två arkitekter som under 10 dagar i juli 2015 var på väg att bygga en lekpark i Padre Ramos och vars design hade en sköldpadda som tema. Arkitekterna skulle bygga lekparken på uppdrag av den spanska NGO:n Amigos de la Tierra (Jordens vänner) som en del i ett avtal med regeringen. Detta för att stödja ekoturismen i området. NGO:n beviljades nära en kvarts miljon Euro för ändamålet från den Europeiska Unionen och Luxemburgs stiftelsen för utveckling och samarbete (Amigos de la Tierra 2016). Jordens vänner skulle utbilda fiskare och äggsamlare i byn i syfte att fungera som ekoguider med omfattande kunskap om de utrotningshotade sköldpaddorna. 
När arkitekterna och jag påbörjade bygget uppdagades att lika mycket som sköldpaddorna skulle räddas i linje med byns satsning på ekoturism, lika mycket ville lokala hotellpotentater och stadshusets tjänstepersoner passa på att berika sig på den nya näringen. Trots att byborna var den viktigaste länken för att rädda sköldpaddorna, blev de dock behandlade som ovälkomna gäster i naturreservatet. Situationen aktualiserade hur rådande satsningar för att hejda den massiva utrotningen av arter också förs i närvaro av djupa maktkonflikter. Detta visar att Chthulucenen är nödvändig men också präglad av intressekonflikter. I Padre Ramos blev detta tydligt genom att stadshuset vägrade att förse fiskebyn med vatten och att hämta sopor, vilket tvingade byborna att borra efter sötvatten och bränna sopor. Deras redan prekära liv betungades med ytterligare risker för kroniska sjukdomar. Byborna som genom projektet skulle rädda sköldpaddorna levde därför själva under ständiga hot om att antingen dö ut som samhälle eller att vräkas från naturreservatet.

Kampen om att bygga lekparken utlöste en principiell strid om att upprätthålla byns rätt att vara kvar i ett naturreservat och denna strid iscensattes kring flagskeppsarten. Kvinnorna rörde sig på gränsen mellan två intressen: Å ena sidan mötte kvinnorna en nationell regering, transnationella forskningsinsatser och europeiska NGO:er som ville få de manliga äggsamlarna att sälja äggen till projektet för att odla ekoturismen i byn. Å andra sidan mötte kvinnorna en lokal regering vars tjänstepersoner i stadshuset, istället för en vårdande inställning till arten och till byborna, dels tog för sig av stränderna för den växande ekoturismen och dels jagade iväg fiskebyn som räddade sköldpaddorna. Genom deras protest visade kvinnorna hur deras vårdande såväl som deras lönearbete var nödvändiga för att byn skulle ta på sig rollen som beskyddare av sköldpaddorna.

\section{Metodologi}

Metodologiskt bygger artikeln på en rhizomatisk ansats (Deleuze \& Guattari 1987) både till fältarbetet och analysen av det. Angående fältarbetet, innebär det rhizomatiska ett upplägg som är varken hierarkiskt eller med en bestämd början eller slut (Grellier 2013), och som hade konkreta implikationer för hur jag kom att tänka om de sociala relationerna i byn. Jag åkte till Nicaragua under min semesterperiod, med knappa ekonomiska resurser, vilket förklarar det kortare fältarbetet. Jag gjorde inga stora förberedelser för att hamna där, utan fick inbjudan att hoppa in i mitten av ett flöde av olika maktrelationer, där jag valde att följa kvinnornas aktioner i Padre Ramos. Det visade sig att det var kvinnorna som förde samtalen, både i planeringen av olydnadsaktionen och genomförandet av lekparken, i handarbetet med smycken med sköldpaddorna som tema, samt i de politiska kontakterna med folk i stadshuset. 
När det kommer till den analytiska ansatsen, när jag började studera kvinnornas tal kunde jag inse att de framförde en sorts rhizovokalitet (Jackson 2003). Alecia Jackson har myntat begreppet genom att blanda Deleuze och Guattaris Rhizoma med musikbegreppet vokalitet. Jackson vill notera röstens performativa förmåga att spridas rumsligt för att höras (Jackson 2003, s.707). För att parafrasera Jackson, här menas att kvinnornas till synes instabila röster sprider sig i andra sammanhang och uppfattas som överdrivna, överträdande, överfyllda och förvånande (ibid.). Som vi kommer att se längre fram innebär detta att kvinnornas röster sprider sig under handlingsförloppen bland markägare, kommunala tjänstepersoner, NOG: er och politiker, på ett sätt som gagnar deras mål. Fältarbetet om kvinnornas rhizovokalitet resulterade $\mathrm{i}$ tio stycken tolv timmars långa sessioner av deltagande observation, något som jag dokumenterade med videokamera. Jag fick göra dessa inspelningar med bybornas samtycke och på deras uppmuntran, och som en antropologisk aktion till nytta för byborna (Jöhnke 2002). Detta innebär att kvinnorna och byborna kunde föra sin rhizovokalitet vidare till allmänheten genom den film som senare redigerades av mig.

Härmed spelade kameran en mycket viktig roll som en teknisk aktant (Smith (2012:333) då den hjälpte till att upprätthålla relationer mellan mig, arkitekterna och byborna. Som jag visar längre fram fick kamerainspelningarna oss alla att stråla samman, och stärka kvinnornas rhizovokalitet för att nå sina delsegrar. Närvaron av en kamera gav kvinnorna en möjlighet att sätta press på folk i stadshuset. Detta då det låg ett underförstått hot om att skicka dessa inspelningar till andra externa aktörer, till exempel nationella tv-stationer. Genom att de bjöd in mig att spela in på deras egna villkor utgjorde kamerainspelningarna en form av videomakt (Velásquez Atehortúa 2015).

\section{Från Antropocenen till Chthulucenen med civil olydnad?}

Människor har alltid utnyttjat andra arter för sin utbredning över planeten. Studier av austronesiska föremål visar att sjöfarare utnyttjade sköldpaddor för koloniseringen av polynesiska öar. Biologerna Wilmé, Waeber och Ganzhorn (2016) hävdar att sjöfarare följde sköldpaddornas migratoriska beteende. Då sköldpaddor mestadels bor i haven kunde sjöfararna följa deras rutter och spåra sköldpaddorna och var de lade sina ägg. Sedan dess har människor använt sköldpaddorna för att äta deras kött och ägg såväl som att använda deras sköld för tillverkning av allehanda föremål som till exempel puderdosor, hårkammar, hårspännen, spegelramar och glasögonbågar (Braga \& Schiavetti 2013). Conway-Gómez (2008) skriver att antropologiska studier från 1950 och 1970-talet har visat att ursprungsfolk i Amazonas åt sköldpaddor vid tiden för européernas koloniala expansion under 
1500-talet. Samma studie visar att fram till introduktionen av fotogen och vegetabiliska oljor använde folk sig av sköldpaddornas ägg som råolja till att elda med i köken samt lysa upp hushållen. Drygt 48 miljoner ägg grävdes fram årligen för att hålla liv i denna sköldpaddsindustri under 1800-talet (Conway-Gómez 2008: 86). Utöver alla dessa konsumtionsformer har människors expansiva jordbruk och urbanisering genom historien förstört de mangroveskogar som sköldpaddorna besöker för att lägga sina ägg i (Jenkins m.fl. 2014).

Diskussionen om utrotningen av sköldpaddorna ingår i debatten om människors påverkan på jordens system de senaste århundraden, där vissa debattörer och forskare inplacerar den i en geologisk epok, Antropocenen (Crutzen 2002). En del klimatforskare hävdar att med den industriella revolutionens början kring 1750-talet har det mänskliga företagandet blivit en intra-agerande del av jordens system (Steffen m.fl. 2011). Temperaturen i världshaven har stigit så pass mycket genom människans utsläpp, vilket har medfört att korallerna riskerar att försvinna inom en snar framtid (Carpenter m.fl. 2008). Som en del av denna massdöd kommer arter med temperaturberoende könsbestämning, som sköldpaddor och andra reptiler, tvingas till samma öde eftersom deras evolutionsförmåga är långsammare än de snabbt växande vattentemperaturen $i$ haven (Janzen 1994). Med en sådan insikt har också behovet av en intersektionell ansats vuxit fram. Detta för att ta itu med massdöden av arter (Twine 2012; Cudworth 2014). Intersektionalitet behövs för att övervinna den fragmentariska förståelsen av klimatkatastrofen. Till exempel har Malm och Hornborg (2014) hävdat att de mest borgerliga samhällslagren som livnär sig på oljeindustrin bör stå till svars för fenomenet, och att epoken därför borde istället kallas Capitolocenen. Mendieta (2019) menar att den koloniala plantageexpansionen med markkoncentration av få ägare har upptagit stora arealer för odling av en och samma sorts växter, plantatiocenen. Di Chiro (2017) hävdar att de vita männen som sitter vid makten och styr alla dessa ekonomiska processer borde kallas den vita (m)antropocenen. Från sina respektive håll argumenterar dessa författare för olikartade kamper i syfte att söka övervinna kapitalism, kolonialism, och patriarkatet som övergripande system. Även om Donna Haraway (Haraway 2016:49) håller med om att dessa system är förkastliga understryker hon dock att vi människor inte är de enda skådespelarna i en Chthulucenens multispecies tid. Denna är „,en tid av multispeciesberättelser, samt praktiker av tillblivelser i tider som förblir torftiga, när världen inte är färdig, och himlen ännu inte fallit“ (Haraway 2016:55). Vi måste därmed lära oss att leva med problemet som det är, eller Stay with the Trouble. Hon anser att vi bör inspireras av naturens förmåga att läka och att kunna återställa sig själv. Haraway menar att vi som art bör inse vad vi har orsakat och börja lära oss av hur „småkryp“ gör i naturen för att bryta ner och kompostera det 
vi tidigare uppfattat vara dött och inte längre brukbart. Hon påtalar att vi är humus, inte homo (Haraway 2016:55). Haraway använder kompost-metaforen för att förklara Chthulucenen. Människan kan här anamma rollen som småkryp som bryter ner rester för att skapa ny jord. Chthulucenen är en multi-speciestid, där vi alla arbetar åt samma håll för att återställa det förstörda.

Men den chthuluceniska omställningen från jägare till vårdare är långt ifrån konfliktfri. Padre Ramos visar att å ena sidan att fattiga människor reduceras nästan till tärande ,småkryp“, som den gröna ekonomin vill städa bort från naturreservatet. Å andra sidan att den gröna ekonomin förtingligar byborna som billig arbetskraft i naturreservatet. Som vi kommer att se i de kommande avsnitten, tvingar denna situation kvinnorna i fiskebyn till chthulucenisk civil olydnad för att kompostera myndigheters ruttna moraliska praktiker och påminna makthavarna om byns och karettsköldpaddornas rätt till att existera. Läkningen av jorden, som Haraway skriver om, innebär med andra ord ofta olydnad och konflikter.

\section{Dag ett-tre: den fabulöse ankomsten och konflikten om fel tomt}

Under första dagen kom arkitekterna och jag till ett gästhem för forskare och volontärer som var beläget på andra sidan viken, i el Estero. Huset låg på en ganska lugn plats, intill ingången till det stora mangroveträsket. Det var ett trähus med två våningar, med utsikt över hela strandremsan. Tidvatten kom in under halva veckan och dränkte stranden, sen försvann det och istället reste sig ett stort trä i mitten av sandbanken.

Vi tittade på soluppgångarna varje morgon eftersom dessa bjöd på alla möjliga nyanser av rosa till orange strax innan gryningen. Sedan var det dags att göra sig i ordning för resan över till fiskebyn. Vi passerade utposten där nyblivna forskningsassistenter höll vakt över ruvningsfältet och forskarlabbet - som såg ut som en scen ur en Alien-film. Men med skillnad att det inte var science-fictionmonster som skulle poppa ut utan små sköldpaddor. Fältet avgränsades av en inhägnad och inuti fanns ett hundratal symmetriskt uppställda påsar. Under varje påse fanns mellan 30 till 90 ägg nergrävda i sanden. Guiderna var alla män som tillbringade tolv timmar i streck på sina vaktpass, mellan klockan 18.00 till klockan 06.00 , på ruvningsstationen och ibland på spaning efter sköldpaddorna som nådde stränderna för att lägga sina ägg.

Båtfärden över gapet mellan vikens ändar bjöd ofta på magiska upplevelser när vi satt i motorbåten. Eftersom vi saknade belysning märkte vi att det började lysa underifrån när vi plöjde igenom marelden av självlysande plankton (fitoplankton). Vi stack ner våra händer i vattnet och det lyste som i en dröm, mitt $\mathrm{i}$ havets mörker kunde vi också titta upp och det var som om tiden stod stilla med 
hela vintergatan som lyste upp längst himlavalvet. Under någon av kvällarna blev vi så varma, efter att ha jobbat under solen hela dagen, att vi var tvungna att svalka oss med ett havsbad innan läggdags. Vi tog med en ficklampa för att hitta fram och gick 300 hundra meter ut på den grunda sandbanken. När det började bli djupare kastade vi oss i vattnet och det var som att träda in i Vintergatan bland miljarder små stjärnor. När vi rörde oss långsamt genom vattnet lyste det vid varje simtag av våra kroppars kontakter med planktonalgerna. Det var denna världen som sköldpaddorna mötte på väg in mot stränderna för att lägga sina ägg. En fabulös ankomst till den osäkra och mödosamma färden till det torra livet på land. Som tur var skulle de inte dödas vid ankomsten av jägare och äggsmugglare. Åtminstone inte på dessa stränder.

När vi kom till Padre Ramos första morgonen möttes vi av kommittén som koordinerade byns arbete under bygget. Vi var fulla av entusiasm och startade genast med att röja tomten. När vi kom tillbaka dagen efter uteblev byborna. Vi försökte reda ut vad som hade hänt. Kring klockan fem på kvällen kom en grupp kvinnor ledda av Reyna, som var byns politiska talesperson, Yoselin A., som var hennes dotter, Yoselin M., och Tomasa. Alla fyra var respekterade kvinnor i byn. De berättade att anledningen till bybornas frånvaro var att tomten som de trodde ägdes av byns hantverkskooperativ tillhörde av någon annan. Härmed förklarade kvinnorna att en bystämma måste hållas för att lösa problemet. Nu var andra dagen förbrukad och arkitekterna samt företrädaren för NGO:n var ganska stressade över att det inte fanns en tomt att bygga på. Vi avslutade dagen med ett löfte om att hålla en bystämma på eftermiddagen under kommande dag.

Till bystämman på tredje dagen kom hela byn, det togs närvarolista och folk engagerades i diskussionen om vilken tomt som var lämpligast. Många pekade på tomten mittemot, som låg i en behaglig skugga av höga Cashewnötsträd. Marken arrenderades till en spanjorska som inte hade varit på plats under de föregående 30 åren. Spanjorskan hade lämnat nycklarna till en av byborna som då och då gick in i tomten för att röja och kratta löv mot en blygsam betalning. Efter byns överenskommelse bestämde alla att de skulle göra anspråk på tomten till parken. Tomasa kontaktade en socialarbetare från stadshuset i Jiquilillo som lovade att köra till mötet för att diskutera situationen med byn. Nu hade bystämman beslutat sig för tomten mittemot, och alla satt ner och väntade på socialarbetaren från stadshuset. När det gått två timmar och inget hände bestämde de sig för att lämna ett röstmeddelande, Tomasa ringde:

Hej, det är från bystämman i Padre Ramos. Ni sade att ni skulle närvara vår bystämma från klockan 14 . Vi har väntat tills nu och vill göra allt på rätt sätt. Men nu har vi bestämt att gå vidare och ockupera tomten för att börja bygga vår park. Ni är härmed underrättade. Detta meddelande undertecknas av hela bystämman i Padre Ramos. 
Tomasa uttalade det magiska ordet ockupera och dess rhizovokalitet (Jackson 2003) skulle sprida ett budskap i stadshusets olika politiska och byråkratiska rum att kvinnorna var på gång med en olydnadsaktion. Medan vi väntade förklarade Tomasa att det viktigaste var att arkitekterna och NGO-folket inte skulle drabbas av deras olydnadsaktion. Efter denna påminnelse fortsatte kvinnorna att diskuskutera hur de vidare skulle hantera situationen.

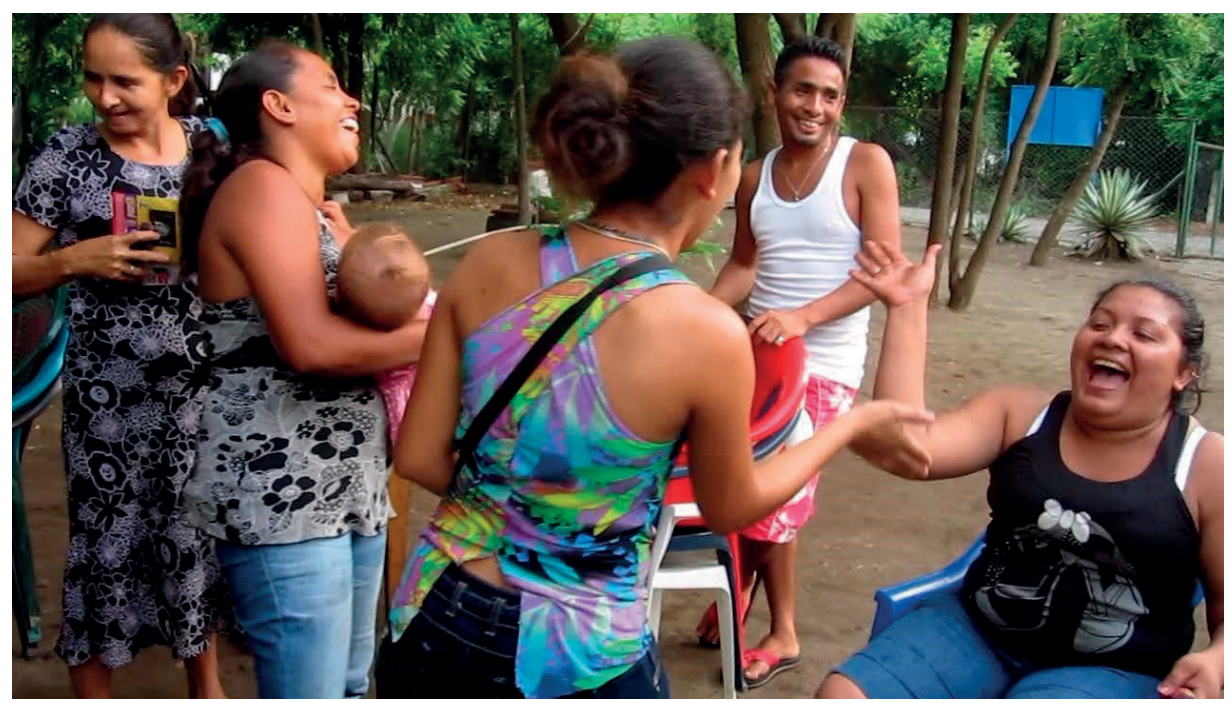

Yoselin A och Yoselin M., skrattar över hur de ska möta stadshusets personal när de ockuperar tomten.

Yoselin Amador: Så en halvtimme efter att tumulten lugnar sig, om någon kommer för att fråga er något, flyttar ni på er och vi tar över.

Tomasa: Vi kommer att sätta vår cucuyo [lysande kryp].

Yoselin Muñoz: Vi fick höra att den här tomten var oskyddad.w

Tomasa: Det här är vad ni ska göra: ... [avbildar en utländsk besökare], inte förstår, inte prata spanska, ingenting, inte ens lite ...

Kvinnorna slog knytnävarna mot varandra medan de skrattade, som vid andra olydnadsaktioner på kontinenten (Velasquez 2014, 2017), då deras rhizovokalitet började ge resultat. Någon timme senare ankom en kvinnlig socialarbetare och en manlig planerare från stadshuset för att lyssna på bybornas anspråk. Vi samlades i naturreservatets öppna undervisningssal. Leo och Fati berättade om projektets design för att efterlikna en sköldpadda och förklarade, att det var brådskade att få en tomt tilldelad för att kunna påbörja arbetet. Kvinnorna i byn insisterade på detta och diskussionen gick in på vilka tomter som kunde vara aktuella. Kvinnorna hade redan bestämt att tomten på andra sidan gatan var den som 
byborna ville ha parken i. Men mannen från stadshuset svarade att det kunde de glömma. Han upplyste att det fanns tre andra tomter som de kunde välja mellan. „Vilka då? Vid stranden?“" Frågade Tomasa, för att påpeka att dessa var de minst attraktiva, för de satt oskyddade mot havet. Mannen svarade att han inte kunde avslöja vilka tomter det var. För att „om jag avslöjar det kommer någon härifrån att ockupera dessa på direkten!“‘. Kvinnorna blev arga, men förblev tysta. Den manliga planeraren fortsatte:

Vi kom hit såhär sent, ni vet att ingen tjänsteperson vågar arbeta såhär sent, och komma ända hit enbart för att träffa er. Men vi gör det, för att vi vill absolut att detta projekt ska stanna här.

Förutom att påminna dem om kvinnornas låga sociala status jämför med NGOfolk, var den kvinnliga socialarbetaren skeptisk till tidpunkten för deras aktion. Hon skällde ut byborna för att de tidigare hade varit alltför inaktiva när kommunfullmäktigen fattade sina beslut. „Vi skulle ha blivit färdiga med parken redan,“ sa hon. Därefter avrundade hon mötet med att erbjuda en bil på morgonen, som kunde köra en kommission till stadshuset för att de kunde prata med borgmästarinnan. I och med utskällningen avlutades mötet med tjänstepersonerna. Men när tjänstepersonerna lämnade mötet stannade kvinnorna kvar i mörkret för att diskutera hur de skulle fortsätta. De kom fram till att en grupp skulle åka till stadshuset för att försöka träffa borgmästarinnan och framföra deras anspråk.

Reyna: Om vi inte får ett besked imorgon under förmiddagen, kommer vi att ockupera tomten efter lunchen och börjar arbeta där under eftermiddagen.

Stella: Och om de ska köra ut oss får de anstränga sig ordentlig, för vi kommer inte lämna tomten självmant!

Mörkret hade redan infunnit sig och vi hade missat båten till gästhuset på andra sidan viken, men voluntärarbetarna i forskningsprojektet hämtade oss till ruvningsstationen för att visa hur det gick till i laboratoriet innan de nykläckta sköldpaddorna släpptes fria.

Haraway (2016) skriver att om människor använder maskiner, i kapitalocenen, för att förgöra världen är de under Chthulucenen, ,inte längre rädda för sitt nära släktskap med djur och maskiner“. Här förespråkar Haraway en realistisk ombyggnad av laboratorier för att rädda liv - för att leva och dö tillsammans med andra arter (op.cit.105). Dels att ombyggnaden skall påminna oss om de modesta möjligheter som kan iscensättas för partiellt helande av planeten genom att våga skapa släktband med medföljande djur (Haraway 2016:10). I Padre Ramos kunde labbet vid ruvningsstationen påminna om detta. 
Vi blev rörda över att se hur ett chthuluceniskt labbarbete i all enkelhet gestaltades i praktiken. Männen på stationen tog DNA-prov på var och en av de tiotals små sköldpaddorna (se bilder 4-7). Luis, en av fiskarna var klädd i en vit rock, gummihandskar och med labbutrustning för att genomföra uppgiften. Ett halvt dussin kvinnliga volontära ekoturister från Frankrike och USA var också med. De blev lika upprymda som vi när vi såg klumpen av små sköldpaddor röra sig i en blå hink. Från hinken fördes ungarna inunder rödljus på operationsbordet, där man tog DNA-prov för att senare frisläppa dem i havet. De ångerfulla upprörda känslor som vi lämnade bakom oss i byn ersattes av varma och upprymda känslor i labbet. Men kvinnornas tumultartade kamp för att bygga lekparken som hyllade insatserna för byns flaggskeppsart kontrasterades med männens spännande, trygga, lugna räddningsinsats i labbet. Denna kontrast visar det motsägelsefulla sättet som människor-djur-relationen gestaltar sig under Chthulucenen. Med denna minnesvärda erfarenhet om födelsekontroll av nykläckta karettsköldpaddor gick vi till sängs. I denna emotionella berg-och-dalbana var vi tillbaka med ångest över hur folk i (kapitaloceniska/mantropoceniska) stadshuset skulle ta emot kvinnornas anspråk på tomten som behövdes till lekparken. Den tredje av tio dagar hade kommit till sitt slut. 
Bildcollage om arbetet med DNA registrering i laboratoriet på ruvningsstationen, innan frisläppningen av sköldpaddsungarna.
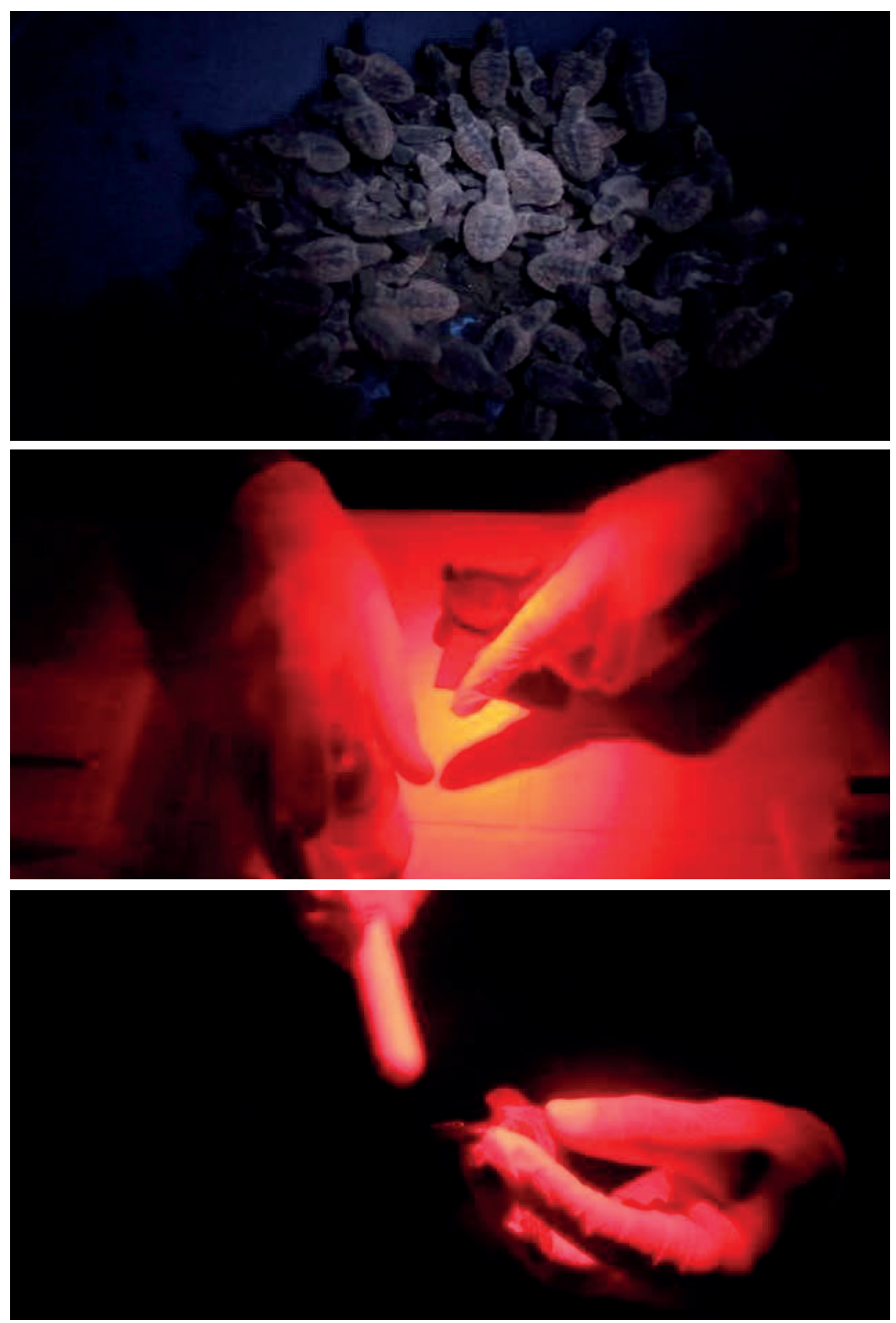


\section{Dag 4: ockupationen: chthulucenisk civil olydnad}

På morgonen startade vi ännu en gång med att beskåda den spektakulära soluppgången. Lugnet var totalt, fåglarna var som vanligt på sin bästa humor, såsom myggorna, och vi togs över till andra sidan för att se hur det gick med hela bygg arbetet. När vi kom fram var kvinnorna redan i samtal med planeringschefen vid hans tjänstebil. Borgmästarinnan lät hälsa genom honom, att stadshuset skulle prioritera en tomt till lekparken, men inte den som byborna bestämde utan en som planeringschefen skulle välja. Kvinnorna var inte alls nöjda med beskedet då planeringschefen hade pekat ut en tomt där det redan bodde en av familjerna i byn.

Tomasa: Det är det blåa huset där borta, vi kan inte vräka dem./.../Vi håller inte med, för de hör till byn. /.../Vi kommer inte heller att skapa bråk mellan oss i byn./.../ Vi är här för att hjälpa varandra, inte för att förstöra för varandra.

I situationen uppträder de olika krafter som driver antropocenen. $\AA$ ena sidan chefens (mantropoceniska och kapitaloceniska) positioner som bryter sammanhållningen i samhället. $\AA$ andra sidan kvinnornas och byns (Chthuluceniska) helande solidaritet. Vi närmade oss samtalet för att lyssna, jag gick med videokameran påslagen på uppmaning av kvinnorna. Det var för egen del ett sätt „att ta itu med problemet" i Haraways anda, genom att dokumentera kvinnornas civila olydnad (Holston 2009) som en antropologisk aktion (Jöhncke 2002: 41) med video-makt (Velasquez 2015). Planeringschefen höll på att förklara att kommunen hade en databas med alla som arrenderade mark. Han förklarade att han var där för att ta reda på vilka som bodde var, och att han sedan skulle gå till kontoret för att kontrollera om dessa personer hade äganderätt eller ett gällande kontrakt. Kvinnorna påminde om att många i Padre Ramos betalade sina markhyror, men att de varken fick kvitton eller någon service i gengäld. Reyna, som var byns politiska språkrör påpekade att de saknade transparens angående hanteringen av dessa tomter.

Yoselin M: Liksom du [till planeringschefen], hur många personer från stadshuset har inte kommit hit för att göra affärer med dessa tomter. Så varför är du så ovillig till att vi ockuperar en tomt ...?

Planeringschefen: Det är inte så att jag inte vill ...

Yoselin M: När vi redan har slut på tiden.

Emilio, som var byns svetsare, närmade sig i sin rullstol och frågade varför byns begäran inte skulle få prioriteras när lekparksprojektet var det enda sättet för byn att erhålla någon form av välfärd. Planeringschefen började bli besvärad över vår närvaro med kameran påslagen. Han uppfattade att kvinnornas och bybornas 
påstridighet kom från arkitekterna, NGO-folket och mig, och nämnde oss i en passiv aggressiv ton. Men kvinnorna insisterade med nya argument om bristande transparens tills Yoselin $\mathrm{M}$ tog initiativet att avrunda samtalet, utifrån det som kvinnorna hade bestämt kvällen innan:

Yoselin M: Då vet du, det är vår position. Vi behöver denna tomt. Från idag klockan två på eftermiddagen börjar vi bygga parken där. Vilken överenskommelse som stadshuset ska sluta med ägaren är inte vårt problem.

Yoselin A: Byn kommer inte att tillåta det [att vräka andra bymedlemmar från sina hus] ...

Reyna: Ni är tvungna att byta tomt...

Yoselin M: Jag tror inte att borgmästarinnan vill förlora en hel by för en person. Reyna: En person som har sin egendom i utlandet.

Yoselin M: Och vi behöver denna tomt för att bygga parken.

Kvinnorna var upprörda över planeringschefens försök att både splittra byns sammanhållning och att förgöra bybornas stöd till borgmästarinnan inför den kommande valrörelsen. De förespråkade att folk på stadshuset skulle „köpa fred“ genom att tilldela en annan tomt till den registrerade ägaren. Detta var en praktik som den högerliberala regeringen före den sandinistiska regeringen införde $\mathrm{i}$ början av 2000-talet (Chavez Metoyer 2000:122). Efter Yoselyn M:s besked blev det tyst några sekunder. Yoselin tittade på ett irriterat sätt, riktade blicken framåt och höjde rösten: ,Såhär blir det, i din närvaro kommer vi att gå in för att rensa denna tomt!“" Hon vände sig om och tydliggjorde:

Yoselin M: Vi kommer att ockupera tomten i er, stadshusherrarnas närvaro! Stella: För ni inte hjälpt oss på sju månader, än mindre nu. Låt oss ockupera den här tomten!

Stella var en av de äldre tonårstjejerna, och hon följde med när alla kvinnor vände sig som höll med Yoselin. De hade redan med sig hinkar och kvastar. Tonårskillarna på cyklarna parkerade en bit ifrån och skrattade nervöst. Kvinnorna var däremot mycket allvarliga och började gå in på tomten.

Yoselin M: Sådär ja! - Herr Miguel! kom för att rensa ingången här! Ta med macheten!

Tidigare antropologisk forskning om marginaliserade kvinnors visar hur deras olydnadsaktioner har varit grundläggande för deltagande demokrati. Men när kvinnor tar plats och styr dessa inbjudna rum görs dessa om till egna uppfunna rum (Holston 2009; Velasquez 2014). Stine Krøijer (2015) har också studerat hur liknande skiften uppstår från samverkan mellan tillfälliga aktioner till mer 
långvariga olydnadsaktioner. Dessa skiften tar ofta plats i kamper som rör allt från för bättre demokratiska villkor till bättre välfärd och boendemiljöer för människor (Krøijer 2019). Under Chthulucenens tecken fortsätter alla dessa aktioner göras inom ramen för deltagande demokrati, för att ännu tydligare gagna andra arter och levande varelser. Här i Padre Ramos visas detta genom att kvinnors olydnadsaktion ingår i byns ansträngningar att hävda sin rätt till att rädda karettsköldpaddorna.

Jag följde med in tillsammans med gruppen och fortsatte spela in händelseutvecklingen. Arkitekterna stannade på avstånd. Miguel skyndade fram med sin machete och skar ner en buske vid en stolpe, som var målad med sandinistiska flaggans färger. De fortsatte med att lyfta upp taggtråden:

Stella: Hallå! [till mig], vi kommer att lämna in dessa inspelningar till kanal åtta.

Yoselin A: Vem som än kommer har vi tagit denna tomt i besittning, punkt slut!/ ...l

Tomasa: Allihopa! Var inte rädda, för vi är alla ägare till detta samhälle här! Vi vräker inte några familjer från vår by.

Maria: [med sin dotter i armarna]: Hur kan de ens föreslå för oss, att vi vräker medlemmar i byn, när det finns tomma tomter!?

Stella tittade in i kameran eftersom de tidigare hade sagt att inspelningen skulle skickas till redaktionen på regeringsvänliga kanal åtta, som hade ringt dem tidigare under dagen. Kameran ingav politisk trygghet när den registrerade detaljerna $\mathrm{i}$ den överträdande rhizovokalitet (Jackson 2003) med vilken kvinnorna iscensatte olydnadsaktionen.

Genom att följa alla regler och officiella procedurer hade kvinnorna sett tillräckligt om hur stadshuset tilldelade tomter utan hänsyn till bybornas akuta behov. Kvinnorna agerade därmed som „småkryp“ som i Haraways chthulucenisk anda i olydnadsaktionen började bita i myndigheternas korrupta praktiker som var i behov av kompostering, återvinning, förändring, eller förnyelse.

Byborna började jobba på tomten under kvinnornas ledning när två män på en motorcykel stannade bredvid. Tomasa och Yoselin $M$ frågade föraren vem han var. Föraren svarade att han ägde tomten varpå kvinnorna krävde att han visade dokument på det. De närmade sig honom med spadar och machetes, samtidigt som de höjde sina röster, vilket mannen uppfattade som hotfullt och sa: „Ni respekterar inte mig, så jag respekterar inte er. Ni överväldigade mig. Om ni verkligen är organiserade handlar det väl om dialog och inte om att begå brott.“ Därefter åkte han iväg på motorcykeln.

Med denna incident blev allt mycket svårare. Larmet om att byborna gjorde inbrott och „hotade med machetes“ nådde stadshuset. Det var som om deras 
rhizovokalitet feltolkades. Den spanska NGO:n ringde för att varna arkitekterna om att inte lämna ut nyinköpta stålrör och cement. Detta tills frågan om tomten löstes med myndigheterna i stadshuset. Kvinnornas aktion exponerade de ruttna och korrupta metoder som stadshuset tillämpade för att tilldela tomter och bygglov, och som alla inblandade i turistsatsningen hade bidragit till att nära. Aktionen visade också hur makthavare bemöter de fattiga när dessa ockuperar mark för sina bosättningar. Efter NGO-beskedet hämtade byborna ett lager av lastpallar och lastbilsdäck. Som när Haraway (2016:8) påpekar om behovet att lära sig av småkryp som komposterar, började kvinnorna bygga lekplatsen med återanvänt material. I samma linje gick arkitekterna till stranden med några män för att söka efter stora stockar som de kunde använda till bänkar. Därpå började landskapsarkitekten Fati och byborna att skissa på hur bildäcken skulle placeras för att avbilda en stor sköldpadda (se bild 6) och därmed gestalta relationen mellan byn och flaggskepsarten, som tydligen avspeglar den multi-species drivkraften bakom hela mobiliseringen. Men utan stålrör och cement till gungorna blev kvinnorna tvingade att åka till stadshuset för att träffa borgmästarinnan om rätten till tomten.

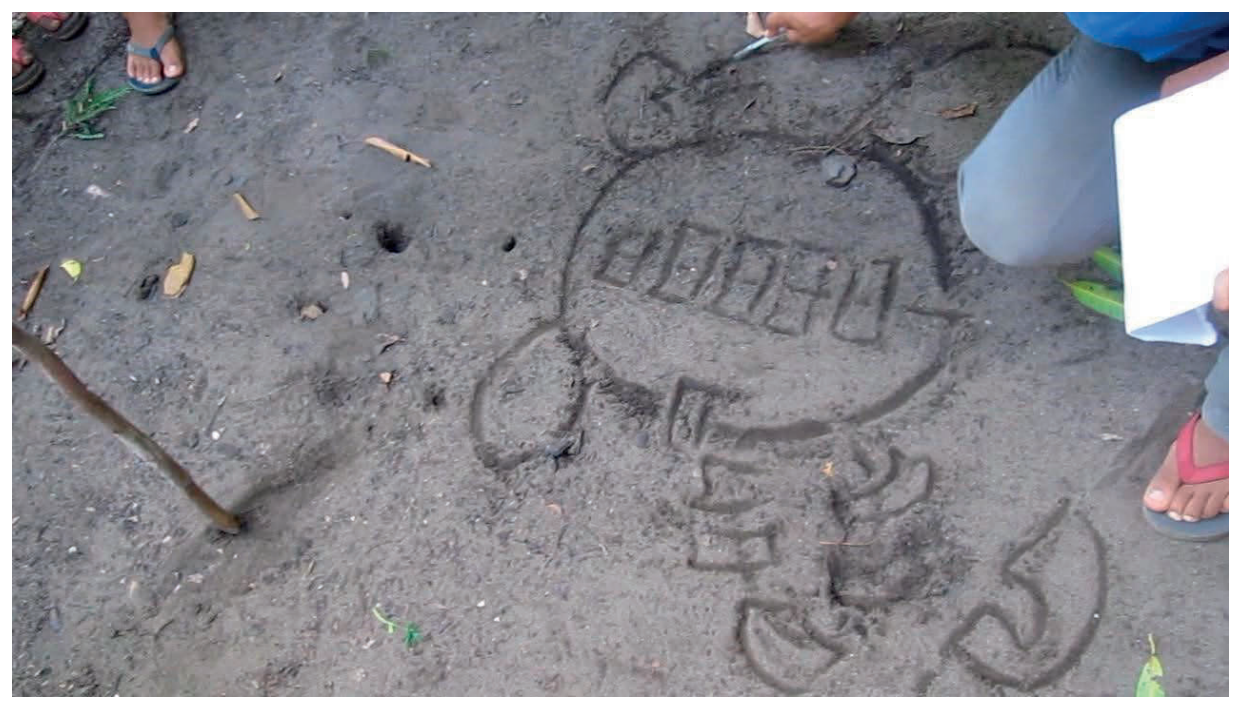

Arkitekten skissar hur "planteringen“ av gamla däck skulle gå till för att avbilda en stor karettsköldpadda. 


\section{Dag 5: „Vi ockuperar stadshuset annars ...“}

Nästa morgon åkte vi buss till stadshuset. Maria, som var med under ockupationen, hade sin åtta månaders gamla dotter med sig. Båda hade feber och blev ganska besvärade av resan eftersom bussen var proppfull. Trots sin feber inledde Maria samtalet med den kvinnliga socialarbetaren som vi hade träffat två kvällar innan. „Vad vi behöver är ett underskrivet papper, vi åker inte härifrån tomhänta," sa hon med barnet i famnen medan socialarbetaren tittade tyst på oss, innan hon ledde in oss till borgmästarinnans väntrum. Vi följde efter socialarbetaren genom den stora vänthallen som var fylld med folk i olika köer. Vi gick genom korridorerna och jag följde efter med kameran påslagen. Vi fick sätta oss och vänta i ett vackert smaragdgrönt receptionsrum som pryddes med stora färggranna målningar av manliga revolutionshjältar. Efter en timmes väntan kom borgmästarinnan in. Jag satte på kameran igen och hon hälsade vänligt på alla och lyssnade på kvinnornas version av historien. Sedan sa hon: „Vi kan inte bygga något utan laglig rätt, men vi ska hjälpa er. Vi kommer till er på fredag.“

Det var inte tillräckligt, sade kvinnorna, eftersom det redan gått fem dagar, och vi bara hade tio dagar på oss att bygga färdigt lekparken. Äganderätten till tomten, som var kärnan i konflikten, var fortfarande olöst.

Borgmästarinnan: Vi har alla intyg om vem som äger tomten.

Reyna: Ja, men det var samma sak med tomten, som vi hade från början, och det visade sig att någon annan ägde den, herren på planeringskontoret tilldelade den.

Borgmästarinnan: Ja, ok, jag brukar inte gå runt och uttala mig om saker jag inte är insatt i. Jag ska ta reda på allt. Vi vill ge er en tomt. Men inte på detta hastiga sätt.

Uzma: Men, medan ni reder ut allt detta kommer projektet att ge sig iväg.

Borgmästarinnan: Nej, de vet hur det brukar bli med allt detta. NGO:n kommer inte att lämna platsen. När det finns vilja kan sakerna bli av, men det måste bygga på lagliga grunder.

Forskning visar att internationella NGO:er i det globala nord ofta initierar ekoturistiska projekt i partnerskap med lokala samhällen i det globala syd (RomeroBrito, Buckley \& Byrne 2016). Nicaragua är ett av länderna som är mest beroende av den typen av finansiering. Andra forskare menar att utländska aktörer tvingar sina perspektiv på lokala samhällen genom de inbjudna rum som projekten skapar (Aguilar-Stöen 2015). Men James Holston har visat att kvinnor kan utveckla dessa inbjudna rum till att fungera som egna uppfunna rum genom allehanda civila olydnadsaktioner (Holston 2009). På grund av Padre Ramos unika läge och på förslag från en transnationell forskargrupp hade byn utsett sköldpaddorna till sin egen flaggskeppsart redan under 2012 (Liles m.fl. 2016:208). Det fanns stora 
förväntningar om att ekosatsningen skulle sätta Padre Ramos på landets ekoturistiska karta. Byborna skulle få bättre livsvillkor samtidigt som sköldpaddorna skulle räddas. Borgmästarinnan kände till att Jordens Vänner inte skulle dra sig ur. Detta speciellt med tanke på att utöver lekparken hade NGO:n fler projekt i området, bland annat att upprätta några vandringsleder runt den närliggande Cosigüina vulkanen. Denna satsning engagerade Turistkontoret och tio småföretag i trakten (Amigos de la Tierra 2016). Borgmästarinnan fortsatte sålunda på sitt spår om laglighet, och kvinnorna på sitt om anspråket på tomten, som de hade ockuperat. Tomasa gick rakt på sak:

Tomasa: Vad vi vill är att stadshuset förhandlar med ägaren av tomten, som vi har ockuperat så att den kan ersättas med en annan tomt, som ni väljer.

Borgmästarinnan: Vi kan inte lova det. Jag vill inte ljuga för er här. Vi jobbar utifrån vad Comandante Daniel [Ortega] uppmanar oss till: 'att göra saker och ting med den regelrätta transparensen'.

I chthulucenisk anda framförde Tomasa byns önskemål om att byta tomter för att bygga lekparken som del av flagskepsartens insatser. Borgmästarinnan avfärdar förslaget genom att hänvisa till den ,regelrätta transparensen“ som bör vägleda kampen mot korruptionen. Men då påminde kvinnorna henne om att denna ,regelrätta transparensen" höll på att missbrukas, när planeringschefen kom till byn med förslag om att avhysa en familj från en av tomterna, på borgmästarinnans uppmaning. Genom att hänvisa till planeringschefens egen rhizovokalitet fick de borgmästarinnan att höja på ögonbrynen. Deras uppmaning till borgmästarinnan att ta ställning $\mathrm{i}$ frågan väckte hennes politiska ego, speciellt när Tomasa tillade att „det är anledningen till att hela byn väntar på er där“. Skulle hon bli del av de korrupta praktikerna som kvinnorna ville „kompostera“ eller skulle hon avstå dessa? Då började borgmästarinnan ändra sin hårda linje.

Borgmästarinnan: Onsdag och torsdag har vi massor av möten ajournerade. Men på fredag kan jag lova, att jag kommer till er med ett besked.

Maria: Men då ryker projektet...vi vill ha ett dokument, där stadshuset tar på sig att bygga parken om NGO:n försvinner.

Uzma: Det är ett projekt som är bra för barnen./.../

Borgmästarinnan: Tror ni att Comandante Daniel och Comandante Rosario inte är intresserade av barnen i landet? Självklart! /.../ vi måste behålla tron, det är det viktigaste.

Eftersom regeringen finansierade projektet genom NGO:ns biståndsmedel från Europa använde sig borgmästarinnan av begreppet tro i brist på materiella resurser. Den sandinistiska poeten Rosario Murillo, då som First Lady, hade använt denna retorik i det offentliga samtalet genom bibliska allegorier om att kvinnorna un- 
der revolutionen födde sig själva och hela nationen (Ortiz-Vilarelle 2018:423). Kvinnorna insisterade, men borgmästarinnan fortsatte med översikter om centralregeringens stora mål och om att behålla tron. Då påminde Reyna om att de $\mathrm{i}$ byn också saknade vatten. Att det var svårt för dem att fortsätta leva på löften och tro. „Ni kan inte ens skicka en vattencistern, än mindre kan ni bygga en lekpark åt oss,“ sa hon. Borgmästarinnan kontrade med att „Vi skickar vattencisterner regelbundet“. „Det stämmer inte!“ utbrast Ramiro, en av männen i byn som följt med oss och som varit helt tyst. Han fortsatte: „Vattencisternerna kommer tills Jiquilillo, och därefter kommer de inte vidare.“

Borgmästarinnan: Korrekt, på fredag kommer vi också med vattencisternen till Padre Ramos.

Tomasa: Vi vill ha denna vattenservice veckovis. För ni vet, att grundvattnet där är förorenat. / . . / Men vad vi diskuterar här och nu är tomten.

Tomasas påminnelse om deras vattenkvalité, som ett tidigare känt problem i stadshuset, var också en hänvisning till deras utsatta position. Borgmästarinnan kramade alla vänligt med löfte om att byborna skulle se henne på plats för att ge besked på fredag. Konflikten var fortfarande olöst och byborna hade inte så mycket mer tid på sig. Trots löftet om vattencisternen gick kvinnorna besvikna från mötet. „Här tar de emot dig bara om du visar pengar,“ sa Maria. De gick tillbaka till socialarbetarens kontor som frågade hur det gick. Maria som ammade sin dotter sa: „Hade vi fătt papper och hennes underskrift, så skulle vi redan nu jobba med parken. Istället är vi här ... och kommer någon med pengar: Ja, välkommen in bara!“"

$\mathrm{Nu}$ pratade hon högt med sitt febriga barn ammande på bröstet, vilket drog till sig uppmärksamhet. Tomasa antydde att de borde göra något mer för att nå resultat, „som talesättet säger, ett enat folk kommer aldrig bli besegrat,“ vilket fick María att komma på nästa idé: „Vet du vad? Vi borde ringa hela byn och be dem att komma hit för att strejka. Och med en strejk här var så säkra på att de ska röra på sig /.../ för att de ska ge oss ett positivt besked redan idag!“

Ortíz-Vilarelle (2018:422) skriver att kvinnor är som farligast när de som mödrar reproducerar rebelliska villkor, som här i fallet när de uttalar sin vilja att „strejka“ mot sin lokala regering. Med tankar om strejk gick kvinnorna tillbaka till borgmästarinnans kontor och väntade. Efter en halvtimmes väntan kom hon ut från ett möte, hälsade förvånad men vänligt, ,är ni fortfarande här!?“ och gick förbi oss. Kvinnorna följde tätt bakom henne. Nu hade de bestämt sig för att det var nu eller aldrig de skulle få tomten till lekparken. De satte hårt mot hårt. Maria följde tätt bakom borgmästarinnan med sin febriga dotter i armarna och uttalade de magiska orden: „Vi kommer att ockupera stadshuset annars.“ Hennes 
mäktiga rhizovokalitet fick borgmästarinnan att tvärstanna, för att sedan vända sig, irriterad, dock lugn.

Borgmästarinnan: Ok. Idag i eftermiddag kommer vi. Jag lovar. Jag vill också prata med herrarna som driver projektet.

Maria: Är ni säker på det? ... byborna är beredda att komma hit för att ockupera stadshuset annars.

Borgmästarinnan: Nä, nej. Projektägarna får inte uppmuntra till illegala handlingar. Jag kommer till er klockan fem. Du har mitt ord på det.

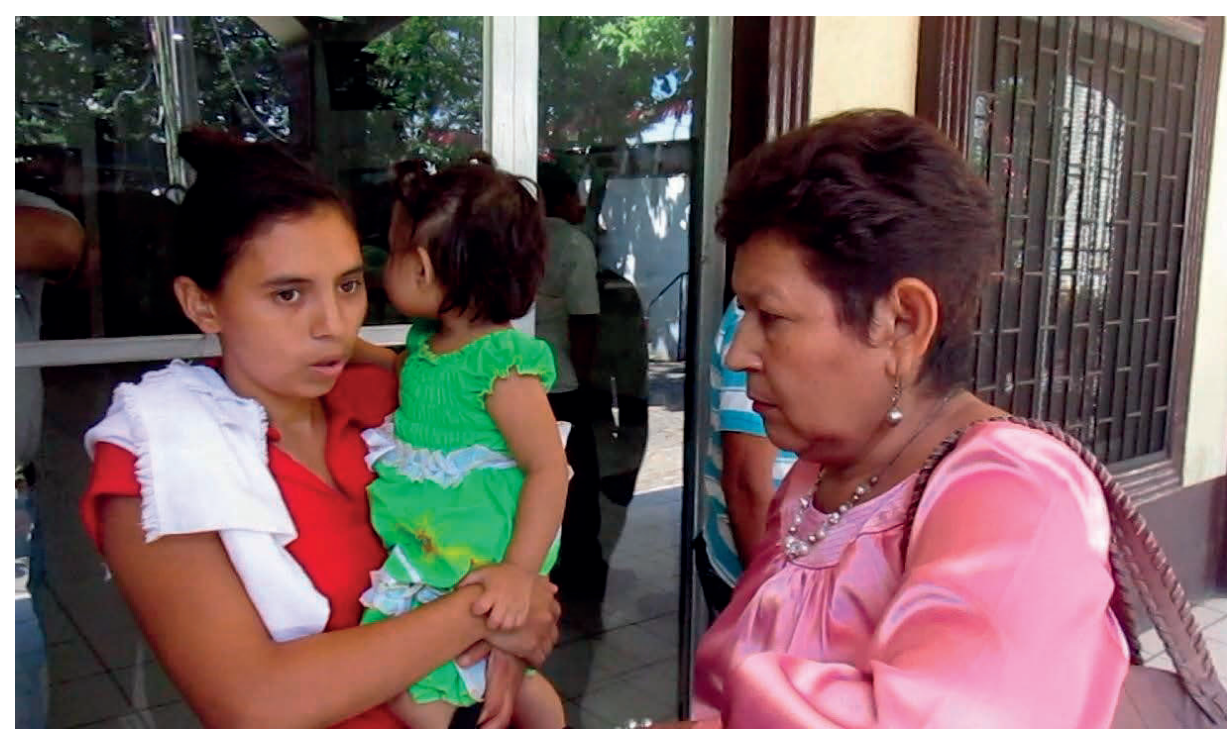

Maria konfronterar borgmästarinnan med hotet om att ockupera stadshuset om byborna inte fick sin tomt till lekparksbyggen

Här framgick det att borgmästarinnan trodde att det var NGO:ns herrar, arkitekterna och kameramannen som låg bakom kvinnornas olydnadsaktion: att kvinnorna själva inte hade kommit på denna offentliga olydnadsaktion. Föreställningen om att latinamerikanska kvinnor är underkastade och avgränsade till den privata sfären i hemmet har problematiserats av Erin O'Connor (2014) med historiskt material om högt uppsatta och överklasskvinnor. Här visar materialet en liknande nyans för kvinnor från lägre samhällsklasser. I och med borgmästarinnans besked lyckades kvinnorna flytta platsen för den fortsatta debatten från stadshuset till byn. Kvinnorna var nu glada över resultatet.

Tomasa: Ingen kommer kunna kasta ut oss ur denna tomt. Som talesättet säger, 'det enade folket kommer aldrig bli besegrat'. 
Parollen kommer från låten El pueblo unido, jamás será vencido från det chilenska musikbandet Quilapayún (Scruggs 2006:11). Sedan 1970-talet har låtens rhizovokalitet gjort den till en aktant i konflikter som förenat folk under demonstrationer mot despotiska regimer längst hela den spanskspråkiga delen av kontinenten. Kvinnorna agerade unisont när de planerade ockupationen, träffade socialarbetarna och planeringschefen och nu i samband med borgmästarinnan. Denna enighet var grundläggande för den seger vars vindar de redan kände förde dem framåt.

Så som de hade tänkt från början av hela flagskeppsartsprojektet var nu formationen med nedgrävda gamla däck (som avbildade en stor sköldpadda) och bänkarna gjorda med stockar funna på stranden på plats. Hela tomten var finkrattad. Kvinnorna hade omvandlat tomten till en lekpark till följd av deras olydnadsaktion. De omvandlade den ockuperade platsen till sin uppfunna plats (Holston 2009; Velasquez A. 2014). Reyna återberättade som i ett familjärt samtal alla detaljer om vem som sade vad, löftet om vattenförsörjning till kampen om tomten till lekparken - allt i kronologisk ordning. Med detta möte förberedde de sig på att ta emot borgmästarinnan senare under eftermiddagen.

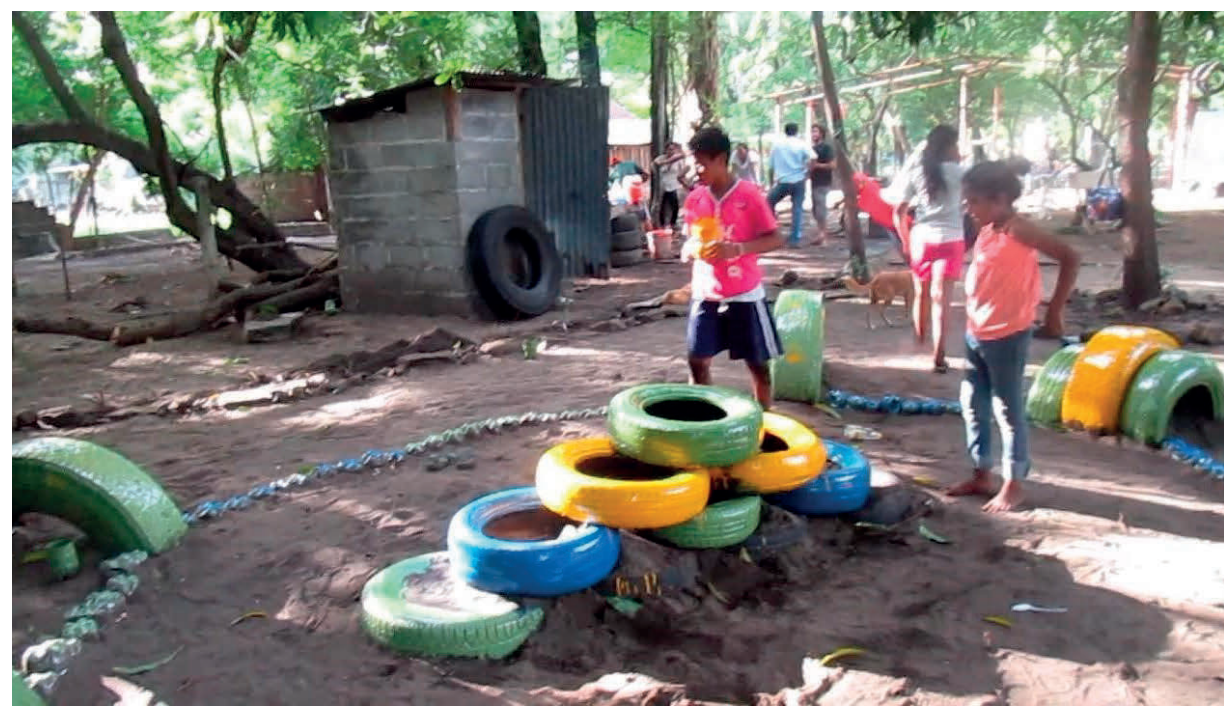

Några av barnen målar klart sköldparkskonstruktionen som består av gamla bildäck

Borgmästarinnan var punktligt och anlände med sin sekreterare och planeringschefen. De blev imponerade av att allting liknade en park redan på två dagars arbete, med formationen som avbildade en sköldpadda i mitten. Hela byn var enade och på plats. Först av allt tog kvinnan i den berörda familjen till ordet för att påpeka att planeringschefen ville vräka hennes familj från sitt hem för att ge 
denna tomten till projektet. Borgmästarinnan bad planeringschefen att förklara sig och be om ursäkt. Gruppledaren för den Sandinistiska majoriteten i stadshuset var också på plats och redovisade att de hade prioriterat fallet och beslutat ge planeringschefen uppdraget att kontakta den rättmätige hyresrättsinnehavaren för ett tomtbyte. Alla blev nöjda, borgmästarinnan avslutade med att skrika ut parollen „Viva Daniel!“ [leve Daniel Ortega] när hon började röra sig på väg ut. Barnen svarade tillbaka i kör: „Queremos parque, queremos parque“ [vi vill ha park, vi vill ha park].

\section{Dag 6 till 10: bygga klart}

Nästa dag kom borgmästarinnan med tomtens ägare, som nu hade gått med på att byta sin tomt. Alla i byn välkomnade hans beslut, vilket avslutade denna intrikata episod om att „köpa fred“ (Chávez Metoyer 2000:122) och äntligen bygga lekparken färdigt. Efteråt blev det fart på arbetet med lekparken. Det vi skulle ha klarat av på tio dagar gjorde vi på fyra dagar. Trots att det var både kvinnorna och männen som arbetade med att bygga parken var det endast männen som fick betalt - kvinnorna arbetade utan lön. Emilio, Svetsaren i byn, klev ner från sin rullstol för att jobba på lekparkens tomt. Tillsammans med hans bror och andra bybor byggde de klätterpyramider och gungor. Marias make fick uppdraget att leda arbetet med att bygga det komposterande utedasset, som arkitekterna hade designat. Kvinnorna arbetade nu mest för nöjes skull efter att ha vunnit striden om tomten med sin rhizovokalitet. De målade skyltar och däckformationen som med karettsköldpaddan i mitten nu gestaltade byns flaggskeppsart.

\section{Avslutande ord}

Skildringen i artikeln visar att byborna hade påbörjat en chthulucenisk omställning av sina kulturella konsumtionsmönster för att rädda karettsköldpaddorna. De var fattiga och de kunde tjäna pengar på att gräva fram äggen och sälja dessa på marknader. Men genom ett forskningsprojekt och i samband med NGO:er fick de insikter om att sköldpaddorna skulle försvinna om ingenting gjordes. Då deras stränder var nästan det enda stället som sköldpaddorna besökte varje år, för att lägga sina ägg, var alliansen och olydnadsaktionen det enda sättet för både byn och sköldpaddorna att ha en gemensam framtid. Vi ser här Chthulucenens strapatser som en ny multi-species-tid när vi strävar efter nya släktband med andra arter. Projektet gestaltade en omställning av byborna - från jägare till vårdare. Som borgmästarinnan tvingades inse var kvinnorna allt annat än underkastade och passiva, så som tidigare forskning om kvinnor i Latinamerika har försökt 
göra gällande (O'Connor 2014). Som tidigare antropologisk forskning om kvinnors civila olydnad har visat: kvinnors mobilisering har spelat en central roll för demokratisering av samhällen (Holston 2009). Men hur kvinnorna uppträder i multi-species insatser är desto mindre utforskat. Dessa släktband mellan kvinnor och sköldpaddor kan illustrera hur relationer under Chthulucenen både helar och utfordrar maktrelationer i samhället. Det var kvinnorna i byn som till större del vågade drömma om lekparken genom att förse arkitekter med visioner för lekparkens design. Det var kvinnorna som först upprördes över hindren, och som sedan ockuperade mark både för deras barns skull och för att iscensätta tanken om sköldpaddorna som flaggskeppsarten för byn. Genom chthulucenisk civil olydnad agerade kvinnorna som komposterande „småkryp“ som dels kunde „ta itu med problemet" om myndigheters ruttna moraliska praktiker för att tilldela bygglov och tomter. Och som dels använde gamla bildäck, lastpallar och stockar från stranden för att skapa ett levande monument som hyllade karettsköldpaddorna.

I den samtid vi lever i, med krav om att ställa om för att rädda arter och landskap från utrotning, visar kvinnor i Padre Ramos vad Chthulucenen handlar om: nya sätt att skapa släktskap, visa solidaritet och förenas med varandra och med andra arter, för att „ta itu med problemen“ om massutrotning av planetens mångfald av livsformer. Chthulucenen visar sig här vara en tid av försoning, men samtidigt en tid av kamp mot alla former av antropogent förtryck. Om antropocenen visar vad vi har skadat och hur vi har gjort det, då visar Chthulucenen hur vi reparerar det i samarbete med och för andra arter, trots alla hinder som vi stöter på.

Kvinnornas rhizovokaliska och chtuluceniska handlingar påminner om att det går att ställa om hela planeten om vi agerar lika transnationellt, solidariskt, enat, stridslystet och framförallt lika komposterande mot våra egna institutioners ruttna praktiker, som helande ,småkryp“.

\section{Tack till}

Jag vill tacka arkitekterna Leo Moreno och Fatima Sandino som bjöd mig till deras arbete. Jag vill även tacka kvinnorna och byborna i Padre Ramos. Ett stort tack riktar jag även till Jenny Schmidt och Torbjörn Friberg för språkkorrekturer. Avslutningsvis ett stort tack till de anonyma granskarna för sina värdefulla förslag och redaktören Stine Krøijers insiktsfulla läsningar under processen. 


\section{Litteratur}

Aguilar-Støen, Mariel

2015 Exploring Participation in New Forms of Environmental Governance. A Case

Study of Payments for Environmental Services in Nicaragua. Environment,

Development and Sustainability 17:941-58. https://doi.org/10.1007/s10668-0149582-1.

Amigos de la Tierra

2016 Apoyo al desarrollo turístico rural sostenible en las Reservas Naturales Estero del Padre Ramos y Volcán Cosigüina. Stöd till den hållbara rurala turismen i Naturreservaten Estero de Padre Ramos och Vulkan Cosigüina. https:// www.tierra.org/.

Braga, Heitor \& Alexandre Schiavetti

2013 Attitudes and Local Ecological Knowledge of Experts Fishermen in Relation to Conservation and Bycatch of Sea Turtles (reptilia: Testudines). Southern Bahia, Brazil. Journal of Ethnobiology and Ethnomedicine 9(3):1-16. DOI:10.1371/ journal.pone.0121435.

Carpenter, Kent, Muhammad Abrar, Greta Aeby, Richard Aronson, Stuart Banks, Andrew Bruckner, Angel Chiriboga et al.

2008 One-Third of Reef-Building Corals Face Elevated Extinction Risk from Climate Change and Local Impacts. Science 321(5888):560-63. DOI:10.1126/ science. 1159196.

Chávez Metoyer, Cynthia

2000 Women and the State in Post-Sandinista Nicaragua. Boulder: Lynne Rienner.

Conway-Gómez, Kristen

2008 Market Integration, Perceived Wealth and Household Consumption of River Turtles (Podocnemis spp.) in Eastern Lowland Bolivia. Journal of Latin American Geography 7(1):85-108. DOI:10.1353/lag.2008.0013.

Crutzen, Paul

2002 Geology of Mankind. Nature 415(3):23.

Cudworth, Erika

2014 Beyond Speciesism. Intersectionality, Critical Sociology and the Human Domination of Other Animals. In: N. Taylor \& R. Twine (eds): The Rise of Critical Animal Studies. From the Margins to the Centre. Pp. 19-35. Abingdon, NY: Routledge.

Deleuze, Gilles \& Felix Guattari

1987 A Thousand Plateaus. Översättning av Brian Massumi. Minneapolis: University of Minnesota Press.

Di Chiro, Giovanna

2017 Welcome to the White (M)Anthropocene? In: S. MacGregor (ed.): Routledge Handbook of Gender and Environment. Pp. 487-505. Abingdon: Routledge.

Haraway, Donna

2016 Staying with the Trouble. Making Kin in the Chthulucene. London: Duke University Press.

Holston, James

2009 Insurgent Citizenship in an Era of Global Urban Peripheries. City \& Society 21(2) 245-67. 
Jackson, Alecia

2003 Rhizovocality. International Journal of Qualitative Studies in Education 16 (5):

693-710. DOI:10.1080/0951839032000142968.

Janzen, Fredric

1994 Climate Change and Temperature-Dependent Sex Determination in Reptiles. Proceedings of the National Academy of Sciences of the United States of America 7487-90.

Jenkins, Richard, Marcelo Tognelli, Philip Bowles, Neil Cox, Jason Brown, et al.

2014 Extinction Risks and the Conservation of Madagascar's Reptiles. PLoS ONE 9(8): 1-14. doi:10.1371/journal.pone.0100173.

Jöhncke, Steffen

2002 I den gode sags tjenste? Om antropologi, stofbrugere og lodrette forbindelser Tidsskriftet Antropologi 45:29-47. https://tidsskrift.dk/tidsskriftetantropologi/ article/view/107373.

Krøijer, Stine

2015 Figurations of the Future. Forms and Temporalities of Left Radical Politics in Northern Europe. New York: Berghahn.

2019 Slow Rupture. The Art of Sneaking in an Occupied Forest. In: M. Holbraad, B. Kapferer \& J.F. Sauma Ruptures (eds): Anthropologies of Discontinuities in Times of Turmoil. Pp. 157-73. London: UCL Press.

Liles, Michael, Markus Peterson, Jeffrey Seminoff, Eduardo Altamirano, Ana Henríquez, Alexander Gaos, Velkiss Gadea, José Urteaga, Perla Torres, Bryan Wallace \& Tarla Peterson

2015a One Size Does not Fit All. Importance of Adjusting Conservation Practices for Endangered Hawksbill Turtles to Address Local Nesting Habitat Needs in the Eastern Pacific Ocean. Biological Conservation 184(April):405-13. https://doi.org/ 10.1016/j.biocon.2015.02.017.

Liles, Michael, Markus Peterson, Yvonna Lincoln, Jeffrey Seminoff, Alexander Gaos \& Tarla Peterson

2015b Connecting International Conservation Priorities with Human Wellbeing in Low-Income Nations. Lessons from Hawksbill Turtle Conservation in El Salvador. Local Environment 20(11):1383-1404, doi:10.1080/13549839.2014.905516.

Liles, Michael, Eduardo Altamirano, Velkiss Gadea, Sofia Chavarría, Ingrid Yañez, David Melero, José Urteaga \& Alexander Gaos

2016 Community Construction through Culturally Rooted Celebration. Turtles All the Way Down. In: T.R. Peterson, H. Ljunggren Bergeå, A.M. Feldpaush-Parker \& K. Raitio (eds): Environmental Communication and Community. Constructive and Destructive Dynamics of Social Transformation. Pp. 204-26. Routledge: London. New York.

Liles, Michael, Tarla Peterson, Jeffrey Seminoff, Alexander Gaos, Eduardo Altamirano, Ana Henríquez, Velkiss Gadea, Sofia Chavarría, José Urteaga, Bryan Wallace \& Markus Peterson

2019 Potential Limitations of Behavioral Plasticity and the Role of Egg Relocation in Climate Change Mitigation for a Thermally Sensitive Endangered Species. Ecology and Evolution 9(4):1603-22. DOI:10.1002/ece3.4774.

Malm, Andreas \& Alf Hornborg

2014 The Geology of Mankind? A Critique of the Anthropocene Narrative. Anthropocene Review 1(1):62-69. 
Mishu

2016 La lucha del pueblo de Nicaragua contra el Canal Interoceánico. 26. Juni. https: //radiozapatista.org/?p=16912.

O'Connor, Erin

2014 Mothers Making Latin America. Gender, Households, and Politics since 1825.

Oxford: Wiley Blackwell.

Ortiz-Vilarelle, Lisa

2018 Milk Poems and Blood Poems. Revolutionary Embodiment and the New Nicaraguan Woman, a/b: Auto/. Biography Studies 33(2):417-36. DOI:10.1080/ 08989575.2018.1445589.

Romero-Brito, Tania, Ralf Buckley \& Jason Byrne

2016 NGO Partnerships in Using Ecotourism for Conservation. Systematic Review and Meta-Analysis. PLoSONE 11(11):1-19. doi:10.1371/journal.pone.0166919.

Scruggs, T.M.

2006 Musik och våldsarvet från slutet av 1900-talet i Centralamerika.Música y el legado de la violencia a finales del siglo XX en Centro América. Trans - Revista Transcultural de Música. https://www.redalyc.org/articulo.oa?id=8.

Smith, Laurel

2012 Decolonizing Hybridity. Indigenous Video, Knowledge, and Diffraction. Cultural Geographies 19(3):329-348.

Steffen, Will, Asa Persson, Lisa Deutsch, Jan Zalasiewicz, Mark Williams, Katherine Richardson, Carole Crumley, Paul Crutzen, Carl Folke, Line Gordon, Mario Molina, Veerabhadran Ramanathan, Johan Rockström, Marten Scheffer, Hans Joachim Schellnhuber \& Uno Svedin

2011 The Anthropocene. From Global Change to Planetary Stewardship. Ambio 40:73961.

Twine, R.

2012 Revealing the "Animal-Industrial Complex". A Concept \& Method for Critical Animal Studies? Journal of Critical Animal Studies 10(1):12-39.

Velásquez Atehortúa, Juan

2014 Barrio Women's Invited and Invented Spaces Against Urban Elitisation in Chacao, Venezuela. Antipode 46(3):835-56.

2015 Episodes of Video Power Supporting Barrio Women in Chacao, Venezuela. Area 47(3):327-33.

2017 Barrio Women's Gendering Practices for Sustainable Urbanism in Caracas, Venezuela. In: A. Lacey (ed.): Women, Urbanization and Sustainability. Practices of Survival, Adaptation and Resistance. Pp. 67-89. London: Palgrave McMillan.

Wilmé, Lucienne, Patrick O. Waeber \& Jörg Ulrich Ganzhorn

2016 Marine Turtles Used to Assist Austronesian Sailors Reaching New Islands. Comptes Rendus - Biologies 339(2):78-82. 